NO.10 Journal of Petroleum Research \& Studies ( JPR \& S)

\title{
Rehabilitating of used Generator Oil by Acid /Bentonite Treatment and Studying of its Performance Evalution
}

Muna Mahmood Khudhair; Kafaa Fadhil Abas; Taghreed Mahdi Hameed; Awali Assad; Wasan Nifal

Ministry of Science and Technology

\section{Abstract}

Used generator lubricant oils are considered hazardous wastes because of their high content of pollutants (thermal degradation products from the base oil and combustion products from fuel and lubricant and external pollutants). Thus, this research aimed to refining the waste oils for economic and environmental purpose.

In this study, it was applied acid / bentonite treatments which include treatment with commercial sulphuric acid followed by adsorption on Iraqi bentonite and study the effect of treated used genarator oil and regards to enhancing their performance in service. The quality checked by evaluation of some important properties i.e. specific gravity, viscosity, flash point, pour point, ash content, and total acid number. The results of treated used oil showed that, specific gravity decreased from 0.898 to 0.894 , viscosity increased from 95 cst to 136 cst. ,flash point increased from $179{ }^{\circ} \mathrm{C}$ to $200{ }^{\circ} \mathrm{C}$, pour point increased from $-13{ }^{\circ} \mathrm{C}$ to $-16{ }^{\circ} \mathrm{C}$, ash content decreased from $1.174 \%$ to $1.0775 \%$ and total acid number decreased from $2.983 \mathrm{mg} \mathrm{KOH} / \mathrm{g}$ to $1.0775 \mathrm{mg} \mathrm{KOH} / \mathrm{g}$.

The results of evaluation of performance of fresh and treated generator oil studied by comparison of some properties such as specific gravity, viscosity, flash point pour point, ash content, and total acid number to the oils in use.

Keywords: Lubricating oils, acid/clay treatment, environmental pollution, acid/clay treatment 
NO.10 Journal of Petroleum Research \& Studies ( JPR \& S)

الخلاصة

تعد زيوت مولدات الطاقة الكهربائية المستهلكة من النفايات الخطرة بسبب محتواها العالي من الملوثات (نواتج التحلل الحراري من النفط والمنتجات الأساسية من وقود الاحتراق وزيوت التشحيم و الملوثات الخارجية). لذلك جرى العمل على تتقية الزيوت المستكة لإعادة استخدامها لأسباب اقتصادية وبيئية.

وتم في هذا البحث استخدام طريقة المعالجة (حامض /بنتونايت) التي تتضمن التعامل مع حامض الكبريتيك التجاري والامتزاز باستخدام البنتونايت العراقي ودراسة تقييم أداء عمل المولدة الكهربائية بعد استخدام الزيت المعالج.

وتم فحص الزيت المعالج بتقييم بعض الخصائص المهمة مثل الكثافة النوعية واللزوجة ودرجة الوميض التها

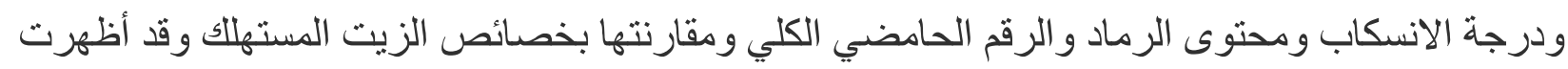
النتائج نقصان في الكثافة النوعية من 0.898 إلى الى 0.894، وزيادة اللزوجة من 95 سنتي ستوك ونك إلى

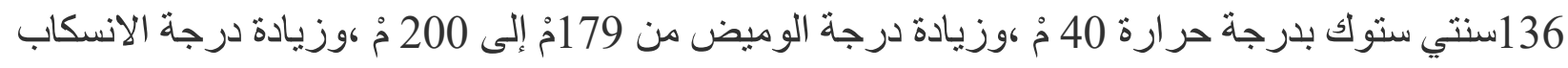

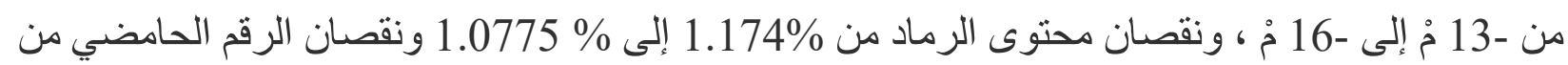

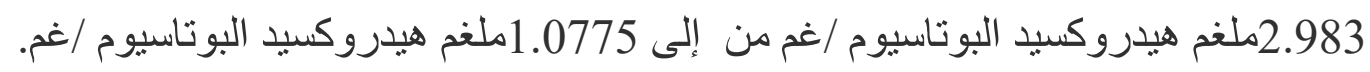

كما تم تقييم أداء الزيت الجديد والمعالج بمقارنة بعض الخصائص المهمة مثل الكثافة النوعية واللزوجة ودرجة الوميض ودرجة الانسكاب ومحتوى الرماد و الرقم الحامضي الكلي للزيوت إثثاء الاستعمال الكلمات المفتاحية: زيوت التزييث، إعادة تدوير الزيوت المستهكة،التلوث البيئي ،طريقة الحامض/الطين.

\section{Introduction}

As with increasing the demand of engines of electric power generators and the lubricating oils, the pollution by used oil is also increasing. Waste oil creates enormous problems if is improperly disposed in the environment (soil, water, and air).Simply one gallon of waste oil can ruin the taste of million gallons of drinking water. Films of oils on the surface of water prevent the replenishment of dissolved oxygen thereby hamper aquatic life, impair 


\section{NO.10 Journal of Petroleum Research \& Studies ( JPR \& S)}

photosynthetic processes and block sunlight. Studies showed that, significant long-term effects have been observed in freshwater fishes with concentration of oil of $310 \mathrm{ppm}$ and in marine life forms at concentration of oil of only 1ppm [EPA, 1994].

Used oil is made up primarily of hydrocarbons, but also contains various additives, which improve its performance in particular applications. The amount and type of additives vary with the intended use of the oil. Hydraulic oils, for example, contain very few additives; some of these additives can be harmful to human health and the environment, while others are harmless. Used oil also contains physical and chemical impurities due to physical contamination, chemical reactions and wear occurring during its use, i.e.; the additive decomposes to polycyclic aromatic hydrocarbons which formed during the incomplete combustion of organic matter, as oils and heavy metal particles that introduced through wear. Used oil include :engine oil,transmission fluid, compressor oil metal working oils ,hydraulic oil ,refrigeration oil ,generator oil,and electrical insulating oil[Alison,2000]. The different type of contaminants, rather than the oil itself, which are of concern when oil is burned in particular ways or used on roads. When used oil is re-refined or reprocessed, the contaminants are not destroyed, but accumulate in the waste sludge. The contaminants render this oily sludge highly toxic. Lubricating oil becomes unfit for further use for two main reasons; accumulation of contaminants in the oil and chemical changes in the oil [Alison, 2000].

Lubricating oils play a dual role of heat transfer and friction reduction that reduce heat generated in internal combustion engine. During usage, lubricating oils undergo changes termed degradation and contamination, which render them ineffective for further application. Lubricating oil goes through normal degredation and about $50 \%$ of it is consumed in the process. The rest of the oil picks up number 
of contamination from the working environment such as residual components of engine fuels, solids from wear process along with corrosion products and dirt,soot,combustion products etc. [Kajdas and Major ,2000].Degradation involves changes in the desired viscometic properties of oil as a result of alteration in the lubricating oil molecular structure caused by cracking, isomerization and polymerization reactions prompted by high temperatures in the running engine .The overall effect of this degradation is the formation of low molecular weight compounds and oxidation products which include polymerized or condensed molecules called gum and sludge.

There are basically three options to deal with the waste oil in the world: (a) dumping the waste oil on land,(b)regeneration of base oil from waste oil,and (c)extracting of heat value of waste oil through compustion process [Rahman et. al.,2008].

The recycling of used oil has more than a four decade tradition. The idea of recycling of used oil was presented in the year of 1930. Initially the used oil was burned to produce energy, and later this oil was re-blended to engine oil after treatment. Recycle of used oil has been carried out by several methods [Kamal and Khan, 2009]. Recycling technology is the most important used oil re-refining. During re-refining the mechanical, physical and chemical contaminations are removed with the following processes: distillation, acidic refining [Abdel-Jabbar et al., 2010], solvent refining [Ogbeide, 2010], clay treatment, hydrogenation [Kamal and Khan, 2009], or combinations of the formers. These processes have different yield and product properties, construction and operational cost. Reclamation of waste lubricanting oil by acid treatment with conc. Sulphuric acid followed by adsorption with fullers earth was carried out [Bhuiyan et.al., 1987] but reclamation with commercial sulphuric acid followed by adsorption with activated clay and its reuse through improvement of properties by addition of different types of additives 


\section{NO.10 Journal of Petroleum Research \& Studies ( JPR \& S)}

have not been investigated sufficiently so far .Sulfuric acid has been used to remove asphaltenic material. The desludge oil is treated with clay [Rahman et al., 2008].

The acid/clay process produced sludge in the following steps: dehydration, acid treatment and clay treatment. If disposed to the environment, separated sludge can cause severe pollution as they are concentrated forms of contaminants. However, these sludges can be used as a modifier for bituminous materials. They can also be used for the preparation of carbon rods as they are rich in carbon content. Moreover, the sludge is completely combustible with net heating value amounting to $4,000 \mathrm{kcal} / \mathrm{kg}$ (Rahman, et al., 2008). If burned, use of appropriate burners and methods for pollution abatement is necessary. Furthermore, it was concluded that treatment of acid sludge with different salt formulations provides a potentially lowest cost source of gilsonite varnish for news ink and also helps in reducing the environmental problem created by re-refining used oil (El-Adly, et al., 1997).

This research aimed to reclaim the used lubricant oil by acid / bentonite treatment include treatment with commercial sulphuric acid followed by adsorption on Iraqi bentonite and the second aim of this research is to study the performance of treated used diesel engine oil after used in gasoline engine and comparison with fresh oil of gasoline engine in use.

The quality checked by evaluation of some important properties i.e.; specific gravity,viscosity,flash point pour point, ash content,and total acid number . 
NO.10 Journal of Petroleum Research \& Studies ( JPR \& S)

\section{Materials and Methods}

\section{$\underline{\text { Materials }}$}

1- Fresh and used generator oils

The tested sample of fresh generator oil was obtained from Shell Company and applied in electrical power generator type $400 \mathrm{Kva}$ Perkin Company for (150 hr as recommended by the supplied company). At the end of the $150 \mathrm{hr}$, the oil was drained and collected from electric power generator machine for analysis as shown in table (1).

Table (1) Used and Fresh Generator Oils Specification

\begin{tabular}{|c|c|c|c|}
\hline Property & $\begin{array}{l}\text { Fresh } \\
\text { Generat } \\
\text { or oil }\end{array}$ & $\begin{array}{l}\text { Used } \\
\text { Gener } \\
\text { ator } \\
\text { oil }\end{array}$ & $\begin{array}{l}\text { Testing Method } \\
\text { ASTM }\end{array}$ \\
\hline Specific gravity at $25^{\circ} \mathrm{C}$ & 0.881 & 0.898 & $\bar{D}$ D941-5 \\
\hline Viscosity at $40^{\circ} \mathrm{C}$,cst & 145 & 95 & $\overline{\mathrm{D} 445}$ \\
\hline Flash point,${ }^{\circ} \mathrm{C}$ & 217 & 179 & D92 \\
\hline Pour point,${ }^{\circ} \mathrm{C}$ & -17 & -13 & D97 \\
\hline $\begin{array}{l}\text { Total acid Number mg KOH } \\
/ \mathrm{g}\end{array}$ & 1.613 & 2.983 & $\bar{D} 644$ \\
\hline Ash Content ,wt $\%$ & 0.8597 & 1.174 & D482-03 \\
\hline
\end{tabular}


2- Technical sulphuric acid

\section{3-Caustic soda}

4- Iraqi bentonite

The Iraqi bentonite sample used in this work was obtained from (State Company of Geological Survey and Mining) and used in one of the recycling process for used oil, chemical composition is listed in table (2).

Table (2) Chemical Composition of Iraqi Bentonite

\begin{tabular}{|l|l|l|l|}
\hline Material & $\begin{array}{l}\text { Percentage Weight } \\
(\%)\end{array}$ & Material & $\begin{array}{l}\text { Percentage weight } \\
(\%)\end{array}$ \\
\hline $\mathrm{SiO}_{2}$ & 54.07 & $\mathrm{MgO}$ & 3.20 \\
\hline $\mathrm{Fe}_{2} \mathrm{O}_{3}$ & 5.59 & $\mathrm{~K}_{2} \mathrm{O}$ & 0.57 \\
\hline $\mathrm{CaO}$ & 5.65 & L.O.I. & 12.40 \\
\hline $\mathrm{SO}_{3}$ & 1.10 & O.M & 7.19 \\
\hline $\mathrm{Na}_{2} \mathrm{O}$ & 0.87 & Moisture & 0.47 \\
\hline $\mathrm{Cl}$ & 0.92 & C.E.C. & 76.59 \\
\hline $\mathrm{Al}_{2} \mathrm{O}_{3}$ & 15.05 & Total C. & 0.93 \\
\hline $\mathrm{TiO}_{2}$ & 0.79 & Mon & 77.00 \\
\hline
\end{tabular}

L.O.I; Lost on ignition, O.M ; Organic Matter, C.E.C.; Cation exchange capacity, Mon; Montmorillonite 
NO.10 Journal of Petroleum Research \& Studies ( JPR \& S)

\section{Experimental Work}

A laboratory scale setup was established for refining used lubricant oil. Figure (1) shows the major steps in processes of acid/bentonite treatment.

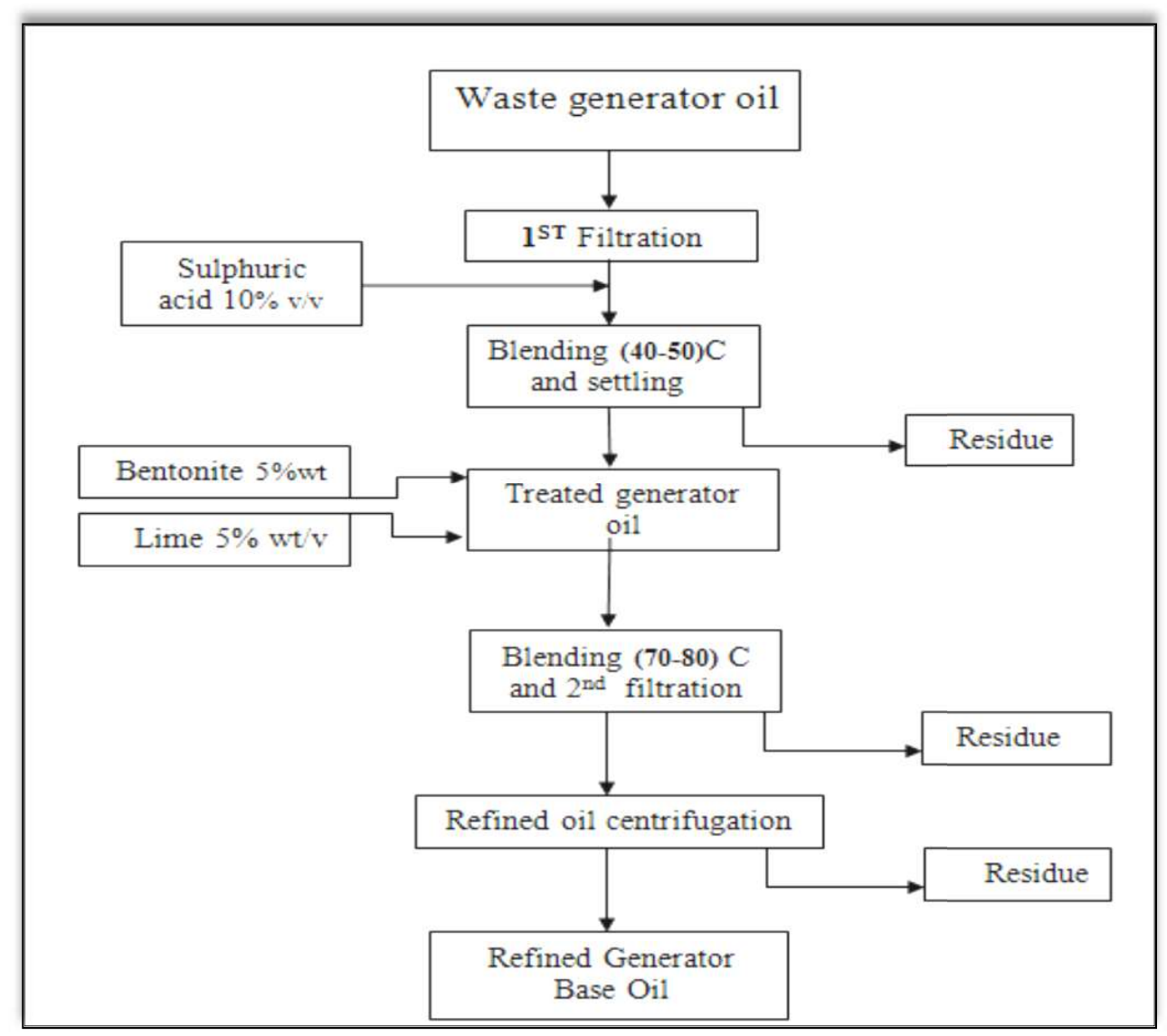

Fig. (1) Laboratory Refining Stages of Waste Generator Oil by Acid/Bentonite

\section{$\underline{\text { Treatment }}$}

1-Treatment Method

A-Sample Filtration

The pretreatment step involved removal of solid particles and water from the waste generator oil by gravity settling. Two separate layers of oil and water were 


\section{NO.10 Journal of Petroleum Research \& Studies ( JPR \& S)}

formed in the gravity settler, wherefrom upper layer of waste oil was collected and sent to the next step for further treatment [Rahman et al., 2008].

The used lubricating oil was filtered to remove impurities such as metal chips, sand, dust, particles, micro impurities that are contained in the oil before treatment. This was done using a funnel with a filter paper, then a vacuum pump was connected to the filtering flask to which the funnel was fixed with the aid of a rubber stopper.

\section{B- Desludging}

$100 \mathrm{~g}$ of waste oil was weighed in a $250 \mathrm{ml}$ beaker. $100 \mathrm{ml}$ of sulfuric acid $(10 \%)$ was added and mixed with waste oil to give a desludging ratio of 10:1. The mixture was then heated with continues stirring to temperature between $40-45{ }^{\circ} \mathrm{C}$ for about 30-40 minutes. The mixture was then allowed to cool and kept overnight for settling. The oil (top layer) was separated by decantation. $5 \mathrm{~g}$ of lime as $(10 \%)$ was added to the oil to neutralize the residue of acid leaving the sludge [Haque et al., 2008].

C- Chemisorption the desludged oil was heated to $70-80{ }^{\circ} \mathrm{C}$ in a $500 \mathrm{ml}$ flask. Iraqi bentonite was added to the heated oil at ratio 20:1.A rapid effervescence and foaming occurred. Heating and stirring were continued for about 60 minutes then the reactor contents were allowed to cool and separate into two phase oil at the top and solid adsorbent at the bottom. The oil was decanted and later filtered with filter paper in glass funnel then the oil was further filtered by centerfuge for 60 minutes and $2000 \mathrm{rpm}$ at room temperature.

2 - Evaluate Performance Engine of power generator of $10 \mathrm{kv}$, working in August and September in temperature of $48 \mathrm{c}^{\circ}$. The engine oil tank capacity was $1 \mathrm{~L}$ and the oil used was from Shell Company. As per original manufactures recommendation, 
NO.10 Journal of Petroleum Research \& Studies ( JPR \& S)

the oil change cycle should take place at every $30 \mathrm{hr}$. Engine oil samples of volume $100 \mathrm{ml}$ were collected from the generator engine. Drawing of samples was ensured from bottom layer of the oil tank. Fresh oil and treated used oil samples were used in engine test to compare the properties of them after 10, 20, 30 hours of working.

\section{Generator Oil Tests}

Flash Point (ASTM D92)

$10 \mathrm{ml}$ of the re-refined lube oil was introduced into a $100 \mathrm{ml}$ beaker and then a thermometer inserted. A beaker was placed on a Bunsen burner. A flame source was brought at intervals to determine the temperature at which a flash appears on the surface on the sample while the lube oil in the beaker was heated.

\section{Pour Point (ASTM D97)}

$20 \mathrm{ml}$ of the lube oil sample was introduced into a container. The lube oil sample was chilled at specific rate. Certain paraffin hydrocarbon (in the form of wax ) will begin to solidify and separate out in crystalline form . The temperature at which this occurs is known as cloud point. Further chilling was continued until lube oil stop to flow. The temperature this occurred is called the pour point temperature.

Specific gravity (ASTM D941-55)

Specific gravity is the ratio of the density of the material to the density of the equal volume of water. This was measured using the hydrometer. The density was observed at $60 \mathrm{f}$ and the value recorded. 


\section{NO.10 Journal of Petroleum Research \& Studies (JPR \& S)}

\section{Viscosity (ASTM D445)}

This was obtained with the viscometer .The re-refined samples obtained by various methods .the fresh oil and the used lube oil were heated on after the other to attain a temperature of $100{ }^{\circ} \mathrm{C}$. The bulb of the clean viscometer was then filled with the hot oil (at $100{ }^{\circ} \mathrm{C}$ ) to the mark while immersed in a thermostat.

\section{Acid Number (ASTM D 664)}

Mix toluene: water:2-propanol by ratio 500:5:495, and transfer100mL to a $200 \mathrm{~mL}$ beaker. Perform a blank test, and obtain blank level. Transfer approx. $2 \mathrm{~g}$ sample to a $200 \mathrm{~mL}$ beaker. Add the above prepared solvent, and make it $100 \mathrm{~mL}$ titrate with the above reagent to obtain total acid number.

\section{Ash Content (ASTM D482-03)}

Weigh 0.5 to $2.0 \mathrm{~g}$ of a test specimen into the crucible. Record the sample weight. Ash the samples using a muffle furnace set to $750{ }^{\circ} \mathrm{C}$. Using an ashing burner, place the crucible over the flame until smoke appears. Immediately ignite the smoke and allow the sample to burn until no more smoke or flame appears. Allow the crucible to cool before placing it in the muffle furnace. Place the crucibles in the muffle furnace for 2 hours. Remove the crucible from the furnace weigh the crucibles and ash and record the weight.

\section{Results and Discussion}

Acid/bentonite treatment was employed in the regeneration of the spent generator oil which includes desludging and adsorption operations, and used the treated oil in engine to evaluate the performance. 
NO.10 Journal of Petroleum Research \& Studies ( JPR \& S)

Acid treatment was carried out to make the oil free from polar compounds like oxidized and acidic products and associated by-products particles in suspension and also not to modify the families of hydrocarbons present in the oil and not altered much during engine use.

In the chemisorptions step, the remaining contaminants were removed by adsorption using Iraqi bentonite as adsorbing agent. To enhance adsorption, fine particles of the adsorbing were used coupled with vigorous stirring . Sufficient time was used so as to allow the complete adsorption.

The experimental results of working hours of treated and fresh generator oils on their specific gravity, viscosity, pour point, ash content, and total acid number are listed in table(3) and table (4).

Table (3) Treated generator oil specification before and after working

\begin{tabular}{|l|l|l|l|l|}
\hline Property & \multicolumn{3}{|l|}{ Working Hours hr } \\
\cline { 2 - 5 } & 0 & 10 & 20 & 30 \\
\hline $\begin{array}{l}\text { Specific gravity at } \\
25^{\circ} \mathrm{C}\end{array}$ & 0.894 & 0.884 & 0.892 & 0.897 \\
\hline Viscosity at $40^{\circ} \mathrm{C}, \mathrm{cst}$ & 136 & 129 & 108 & 87 \\
\hline $\begin{array}{l}\text { Pour point },{ }^{\circ} \mathrm{C} \\
\text { Total acid Number }\end{array}$ & -16 & -15 & -13 & -11 \\
\hline mg KOH $/ g$ & 1.361 & 5.291 & 6.145 & 8.112 \\
\hline Ash Content ,wt $\%$ & 1.077 & 1.492 & 1.603 & 1.8 \\
\hline
\end{tabular}


Table (4) Fresh generator oil specification before and after working

\begin{tabular}{|c|c|c|c|c|}
\hline \multirow[t]{2}{*}{ Property } & \multicolumn{4}{|c|}{ Working Hours hr } \\
\hline & 0 & 10 & 20 & 30 \\
\hline $\begin{array}{lll}\text { Specific } & \text { gravity at } \\
25^{\circ} \mathrm{C} & & \end{array}$ & 0.881 & 0.884 & 0.896 & 0.898 \\
\hline Viscosity at $40^{\circ} \mathrm{C}, \mathrm{cst}$ & 145 & 124 & 114 & 94 \\
\hline Pour point,${ }^{\circ} \mathrm{C}$ & -17 & -16 & -15 & -13 \\
\hline $\begin{array}{l}\text { Total acid Number mg } \\
\mathrm{KOH} / \mathrm{g}\end{array}$ & 1.613 & 2.021 & 2.53 & 3.002 \\
\hline Ash Content ,wt $\%$ & 0.855 & 0.91 & 0.949 & 1.08 \\
\hline
\end{tabular}

Specific Gravity

The specific gravity value for the used oil is higher than that of fresh oil and this difference is depending on the type of contamination [Udonne, 2011]. Figure(2) show the specific gravity for the fresh ,used, treated lubricant generator oils. 
NO.10 Journal of Petroleum Research \& Studies ( JPR \& S)

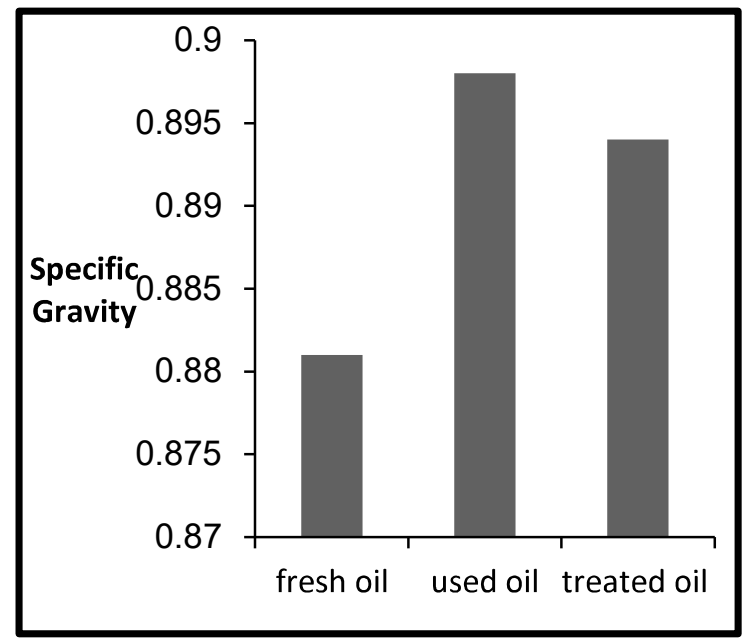

Fig. (2) The Effect of Treatment of Used Generator Oil on its Specific Gravity

Figure (3) shows the specific gravity of fresh and treated oil on use has been increased with increasing the working hours and this is because the increasing of contaminating materials in oils [Udonne, 2011].

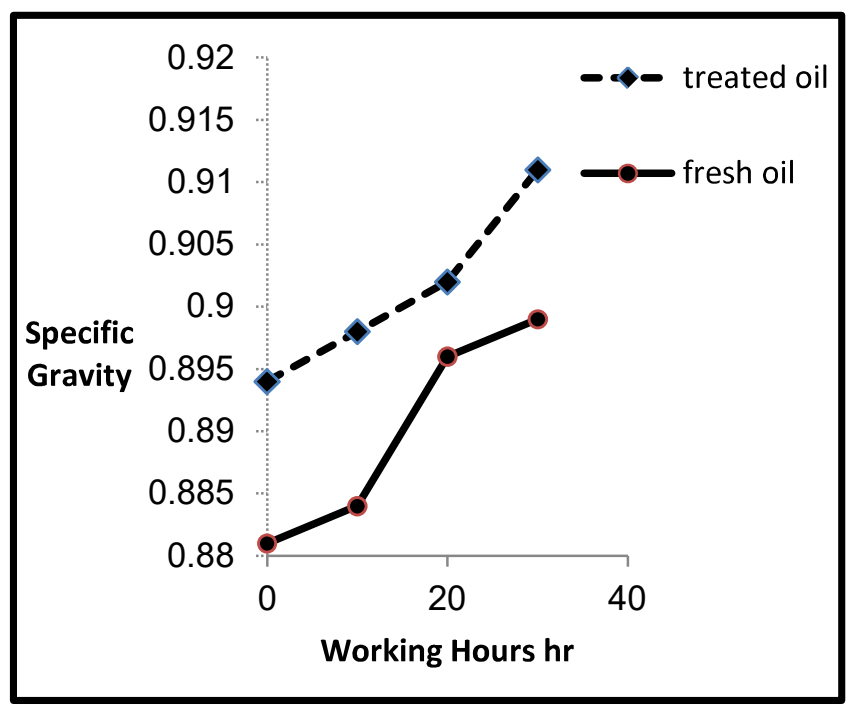

Fig. (3) The Effect of Working Hours of Fresh and Treated Generator Oil on their Specific Gravity

Viscosity

Viscosity is the most important consideration of choosing lubricating oils. The strength of the oil film is approximately proportional to its viscosity, so the higher 


\section{NO.10 Journal of Petroleum Research \& Studies ( JPR \& S)}

viscosity indicates the stronger strength of the oil film. The increase or decrease in viscosity can occur due to oxidation or contamination with insoluble and fuel [Tran et al., 1991].

From figure (4), we can see a decrease in viscosity of the used generator oil in comparison with the fresh oil. Viscosity decrease can be caused by dilution with light fuel.

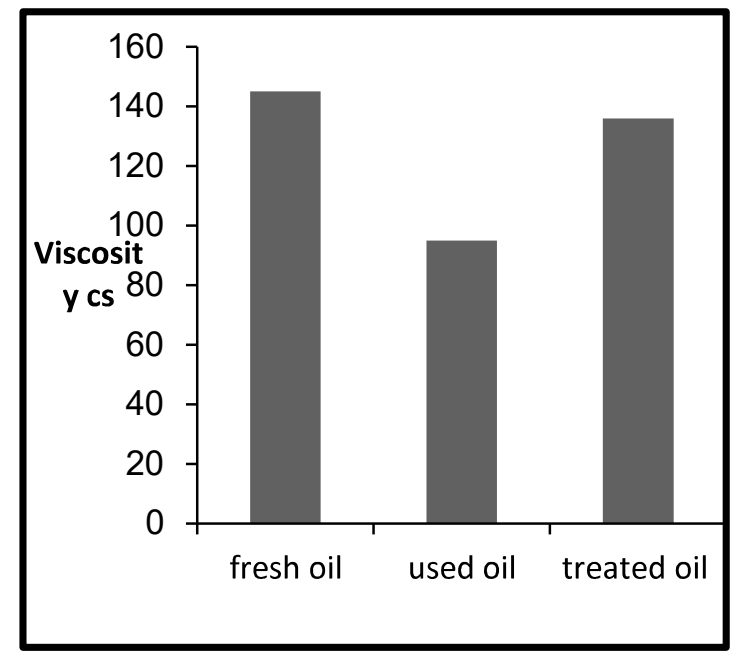

Fig. (4) The Effect of Treatment of Used Generator Oil on its Viscosity

Typically, diesel engine oil will have a higher viscosity. If we were to put this higher viscosity in a gasoline engine, several problems might arise. The first is heat generation from internal fluid frictionand this heat affects the life of an oil, thus we use the treated oil that has low viscosity and put it in gasoline engine.

Figure (5) shows that, decreasing of viscosity of fresh and treated oils with increasing of working hours of engine. Viscosity decrease can be caused by dilution with light fuel [Tran et al., 1991]. 
NO.10 Journal of Petroleum Research \& Studies ( JPR \& S)

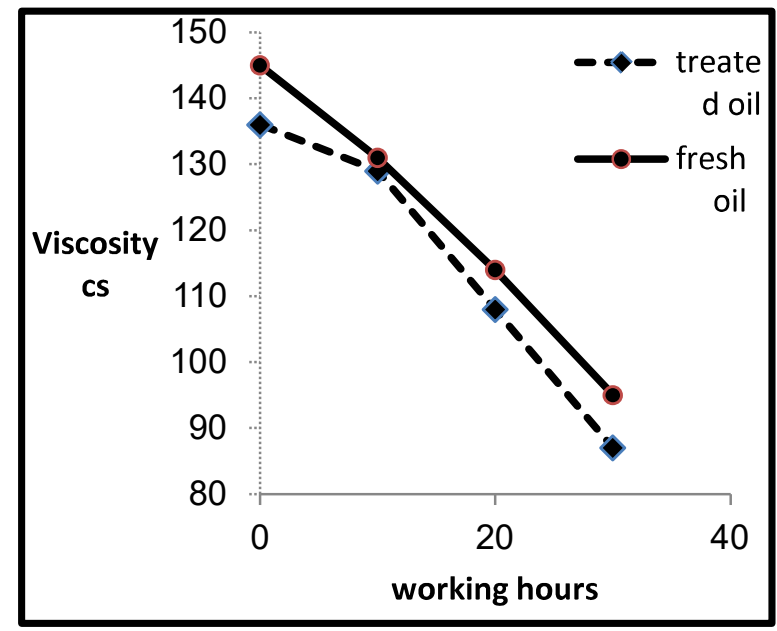

Fig. (5) The Effect of Working Hours of Fresh and Treated Generator Oil on their Viscosity

Flash Point

From figure (6), the used generator oil shows a decrease in flash point in comparison with the fresh that means there is a fuel contamination of the oil, in addition it could be as result of the presence of light ends of oils when undergoing combustion and oxidation at high temperature of the combustion engine, during that the oil breaks down into component parts, which include some light ends[Friday et al, 2008].

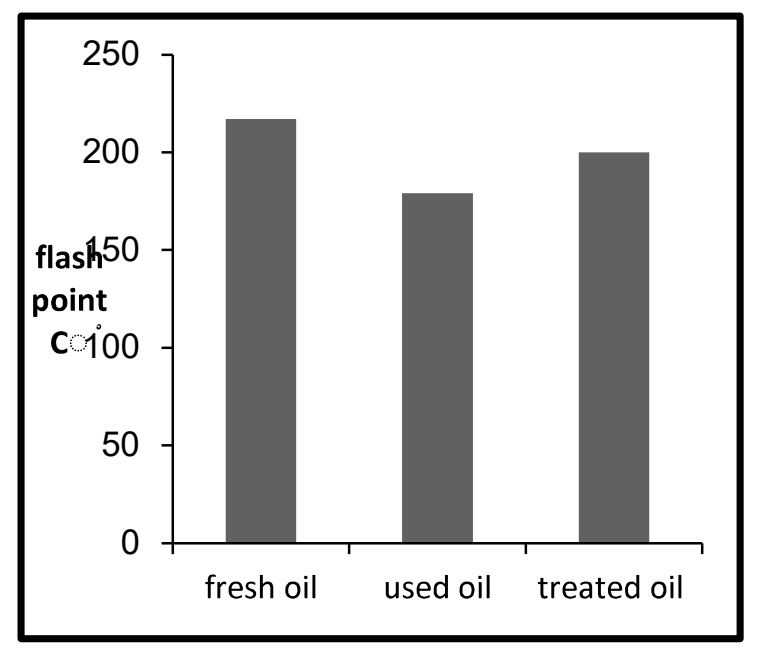

Fig. (6) The Effect of Treatment of Used Oil on its Flash Point Generator 


\section{NO.10 Journal of Petroleum Research \& Studies (JPR \& S)}

\section{Pour Point}

Figure (7) shows that, the pour point of the used generator oil is high, this is because of the degradation of additive in lube oil. Pour point especially is of interest when oil must be under relatively cold condition. Pour point varies widely depending on the base, the source of the lube oil and the method of refining, especially if dewaxing has been done [Udonne, 2011].

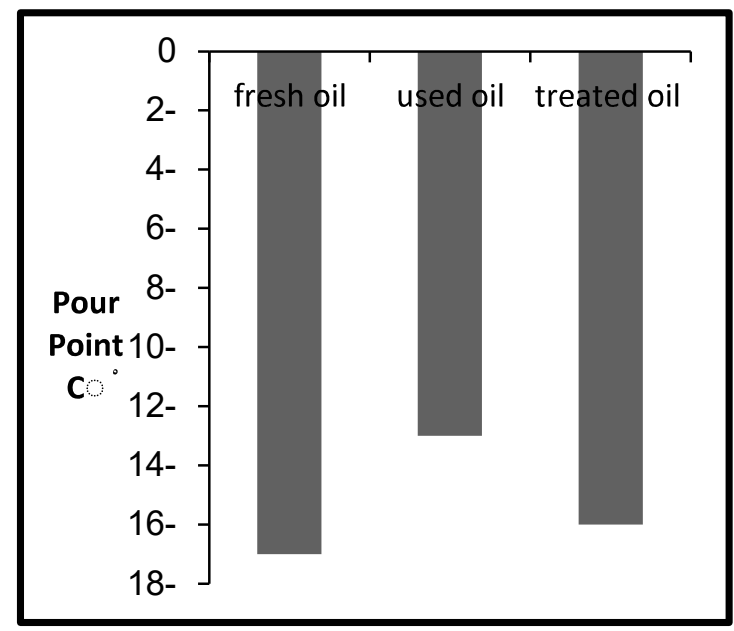

Fig. (7) The Effect of Treatment of Used Generator Oil on its Pour Point

As the lubricant oils are used, the long aliphatic chains attached to the aromatic ring is separated and cracked as a result of oxidation. The oxidation products such as aldehydes and ketones have a low pour point so as we may notice the pour point of the fresh and treated oils is increasing with the increasing the working hours of engine [Udonne, 2011] as shown in figure (8). 
NO.10 Journal of Petroleum Research \& Studies ( JPR \& S)

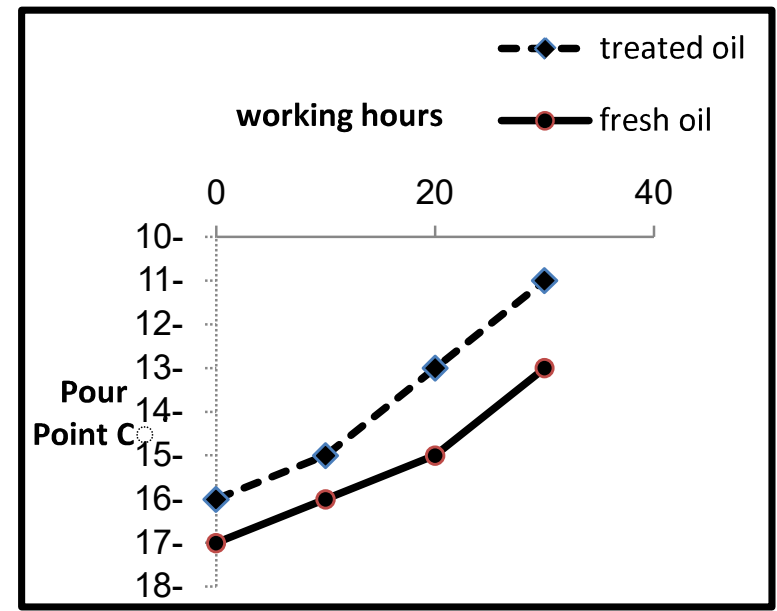

Fig. (8) The Effect of Working Hours of Fresh and Treated Generator Oil on Their Pour Point

\section{Total Acid Number}

Total acid Number (TAN) is the quantity of acid or acid-like derivatives in the lubricant. The TAN of new oil is not necessarily nill since oil additives can be acidic in nature. From figure (9), it is observe that the acid number of used generator oil has high value. The increases in TAN usually related to oil oxidation or contamination with an acidic product [Udonne, 2011].

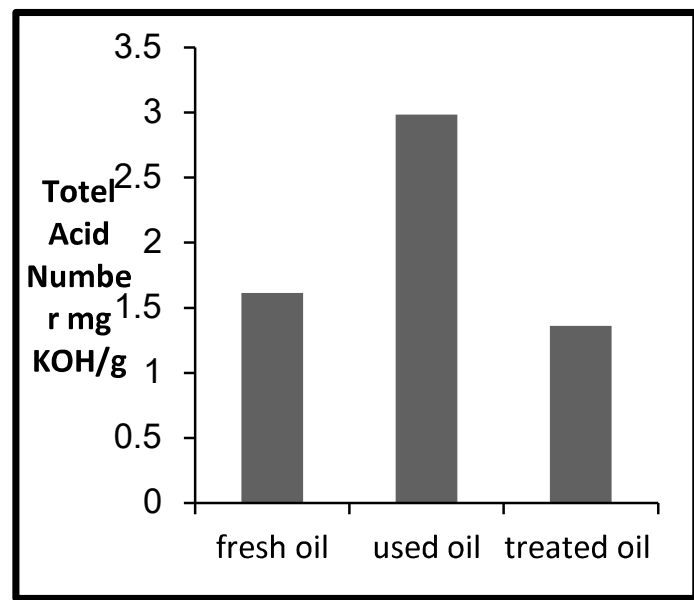

Fig. (9) The Effect of Treatment of Used Generator Oil on its Total Acid Number 


\section{NO.10 Journal of Petroleum Research \& Studies ( JPR \& S)}

Acid number is used as a guide in the quality control of lubricating oil and also as a measure of lubricant degradation in service. These results indicate those organic and inorganic acids, esters, phenolic compounds, lactones; resins etc. The effect of working hours of fresh and treated oils on their acid number has been shown in figure (10).

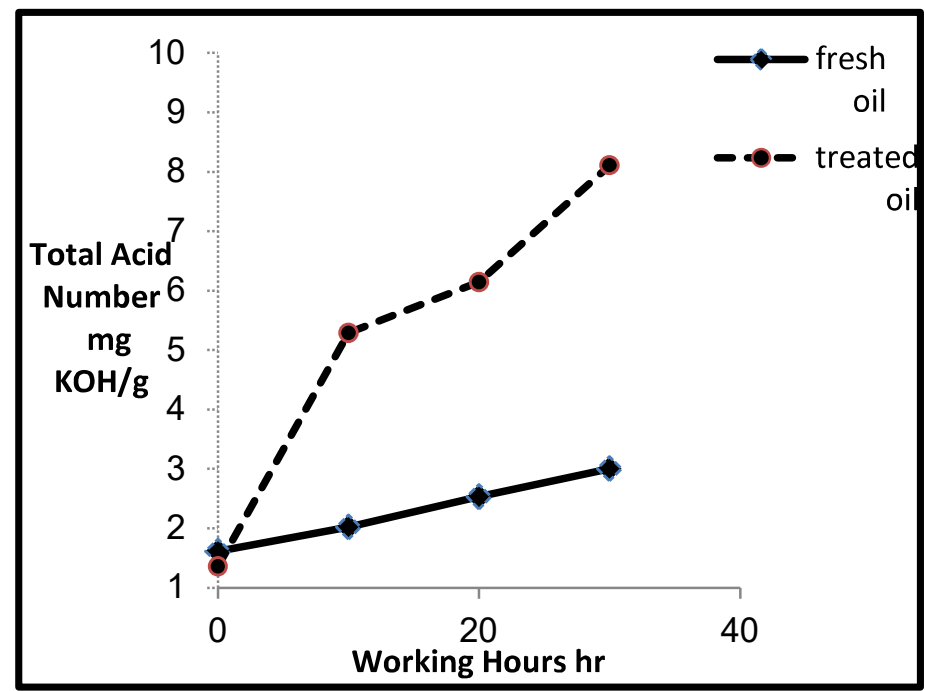

Fig. (10) The Effect of Working Hours of Treated Generator Oil on Their Total Acid

Number

\section{Ash Content}

Figure (11), shows the ash content of used oil is high because of the presence of metals in lubricating oil that come from various sources, such as wear, contamination and additives. Wear metals result from friction or corrosion of the engine components, for example, pistons, bearings, etc. during operation. Contamination can come from dirt, leaks or residual metal pieces. Detergent additives, anti-oxidants, and anti-wear agents are added to improve lubricity and to reduce engine wear [Burrows et al., 1965]. 
NO.10 Journal of Petroleum Research \& Studies ( JPR \& S)

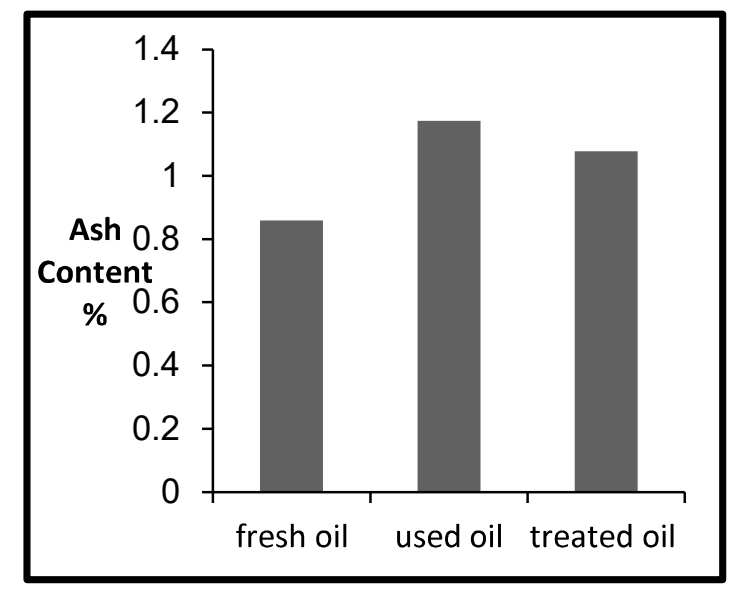

Fig. (11) The Effect of Treatment of Used Generator Oil on its Ash Content

Diesel engine oil has more additives per volume, thus figure (12) shows the increasing ash content of treated generator oils with increasing of working hours of engine.

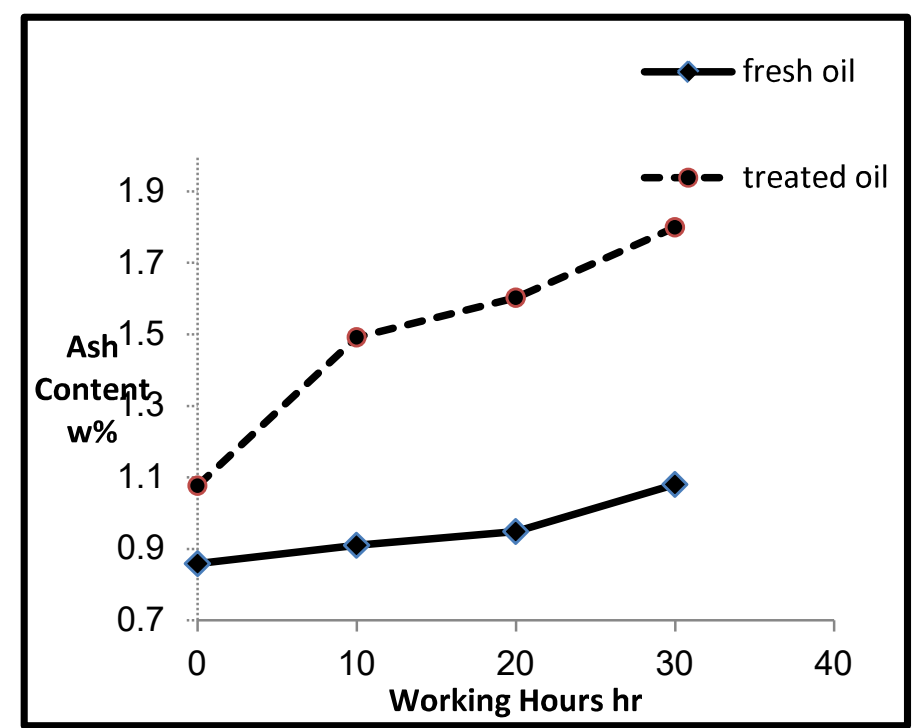

Fig. (12) The Effect of Working Hours of Fresh Treated Generator Oil on their Ash Content 


\section{Conclusion}

1- Regeneration of waste oils gives rise to a significant reduction in environmental impacts as compared to the primary production of lubricants and as compared to incineration as an alternative recovery option.

2- The effect of the re-refining used oil by using acid/bentonite processes were Studied and compared with the fresh oil and it is clear that it is a good technique for the removal of impurities from used oil which enhances desired characteristics.

3- Yield is a very important factor as it reflect the effectiveness of the process and has direct relation to the process cost .The yield of acid/bentonite process was found to be $60.3 \%$ that may be referring to removal of high amount of contaminants .

4-Good results of evaluation of performance of fresh and treated generator oil obtained by comparison of some properties such as specific gravity, viscosity, flash point, pour point, to the oils in use but they need more work to study to use additives to improve the ash content and total acid number . 
NO.10 Journal of Petroleum Research \& Studies ( JPR \& S)

\section{References}

1. Alison H.; "Used Oil Recovery, Reuse and Disposal in New Zealand Issue and Options", Published by the Ministry for the Environment, 7-10, (2000).

2. Abdel-Jabbar N.M., Al Zubaidy E.A.H., Mehrvar M.; "Waste lubricating oil treatment by adsorption process using different adsorbents", World Academy of Science, Engineering and Technology, 62, 9-12,(2010) .

3. Bhuiyan T.A., Haque M.N., Eusuf M.; "Reclamation of used lubricating oils.Part 1 Improvement of viscosity index and colour with pure conc. Sulfuric Acids", J.Sci.Ind.Res. 22(1-4); 61-67, (1987).

4. Burrows J. A. , Heerdt J. C. , Willis J. B. ; "Determination of Wear Metals in Used Lubricating Oils by Atomic Absorption Spectrometry". Anal. Chem., 37 (4), 579-582, (I965).

5. El-Adly R.A., Moustafa Y.M., Omar A.M.A.; "Gilsonite varnish from acid sludge produced by the recovery of used lubricating oil", Pigment \& Resin Technology, 26(4), 22-224, (1997) .

6. Friday O.N., Bamidele I.O., Kayode O, A., Luter L; "Comparative Investigation of Wear Metals in Virgin and Used Lubricant Oils", Terrestrial Aquatic Environmental Toxicology, 2(1), 38-43, (2008).

7. Josiah P.N. and Ikiensikimama S.S.; "Effect of desludging and absorption ratios on recovery pour fuel oil (LPFO) from spent engine oil”, Chemical Engineering Research Bulletin, 14, 24-28., (2010). 
8. Haque M.N., Miah M.Y., Ashruf S.A., Islam M.R., and Das A.K., "Effect of Acid Washing and Additives on Qualities of Waste Lubricanting Oil", Bangladesh J.Sci.Ind.Res. 43(4), 529-536., (2008).

9. Kamal A., Khan F.; "Effect of extraction and adsorption on re-refining of used lubricating oil”, Oil \& Gas Science and Technology, 64 (2), 191-197, (2009).

10.Kajdas C. and Major; "pathways for used oil disposal and recycling.Part "1, Tribotest, 7(1); 61-74, (2000).

11.Rahman M.,Siddique T.,Samdani S., Kabir K; "Effect of Operating Variables on Regeneration of Base -Oil by Conventional Acid-Clay Method ",Chemical Engineering ResearchBulletin, 12:24-27,( 2008).

12.Waste Oil and Filter Recycling, City of Sierra Madre: California Homepage, (2008).

13.Center for Environmental Research Information, Office of Research and Development, US EPA, Cincinnati, Environmentaal Regulation and Technology: Managing Used Motor Oil, (1994).

14. Ogbeide S.O.; "An investigation to the recycling of spent engine oil", Journal of Engineering Science and Technology Review 3 (1), 32-35.

15.Olugboji O. A. and Ogunwole, O. A., (2008), "Use of spent engine oil", AU J.T. 12(1): 67-71 (2010).

16.Udonne J. D.; "A comparative study of recycling of used lubrication Oils using distillation, acid and activated charcoal with clay methods", Journal of Petroleum and Gas Engineering, Vol. 2 (2), pp. 12-19,(2011) .

17.Tran T. N. and Roman M. B. "Determination of metals in lubricating oil by ICP-AES”, Instruments Work, Vol. 2, 1-5, (1991). 